J. Schmeck

T. Koch

B. Patt

A. Heller

H. Neuhof

K. van Ackern

\section{The role of endothelin-1 as a mediator of the pressure response after air embolism in blood perfused lungs}

J. Schmeck ( $)$. T. Koch - A. Heller .

K. van Ackern

Institute of Anesthesiology

and Operative Intensive Care Medicine, Faculty of Clinical Medicine Mannheim,

University of Heidelberg,

Theodor-Kutzer-Ufer,

D-68135 Mannheim, Germany

Tel.: + 496213832422

Fax: +496213833806

B. Patt - H. Neuhof

Division of Clinical Pathophysiology and Experimental Medicine,

Department of Internal Medicine,

University of Giessen, Germany

\section{Abstract Objective: It is well} known that lung embolism is associated with an increase in pulmonary vascular resistance. Since the mechanisms of pulmonary vascular reactions during embolism are still unclear, the aim of this study was to investigate the potential involvement of endothelin-1 (ET-1) and thromboxane $\mathrm{A}_{2}\left(\mathrm{TXA}_{2}\right)$ as mediators of the pulmonary artery pressure (PAP) increase after embolism using the selective $\mathrm{ET}_{\mathrm{A}}$ receptor antagonist LU135252 [1], the $\mathrm{ET}_{\mathrm{B}}$ receptor antagonist BQ788 [2], and the cyclooxygenase inhibitor diclofenac. Design: Prospective experimental study in rabbits.

Setting: Experimental laboratory in a university teaching hospital.

Subjects: 36 adult rabbits of either sex.

Interventions: The experiments were performed in 36 isolated and ventilated rabbit lungs which were perfused with a buffer solution containing $10 \%$ of autologous blood. Embolism was induced by the injection of $0.75 \mathrm{ml}$ air into the pulmonary artery.

Measurements and results: PAP and lung weight, reflecting edema formation, were continuously recorded. Perfusate samples were drawn intermittently to determine $\mathrm{TXA}_{2}$ and ET- 1 concentrations, Air injection resulted in an immediate increase in PAP up to $22.8 \pm 1.4 \mathrm{~mm}$ $\mathrm{Hg}$ at $2.5 \mathrm{~min}$ (control, $n=6$ ), which was parallelled by an enhanced generation of TXA . No relevant edema formation occurred during the observation period. Pretreatment with the $E T_{A}$ receptor antagonist LU135252 significantly reduced the pressure reaction after air embolism $(p<0.001)$ whereas the $\mathrm{ET}_{\mathrm{B}}$ receptor antagonist BQ788 $(n=6)$ was without marked effects. The administration of diclofenac $(n=6)$ did not alter the PAP increase $2.5 \mathrm{~min}$ after embolism, but significantly reduced the pressure reaction during the further observation period $(p<0.001)$. The application of LU135252 and diclofenac together $(n=6)$ also significantly reduced the PAP increase from $2.5 \mathrm{~min}$ during the total observation period $(p<0.001)$.

Conclusions: The acute pressure reaction after air embolism is mainly mediated via $E T-1$ by an $E T_{A}$ receptor related mechanism. TXA 2 seems to maintain this reaction for a longer time.

Key words Air injection Embolism - Endothelin . Thromboxane - Vascular resistance 


\section{Introduction}

Since endothelin-1 (ET-1) was first described in 1988 [1], the effects of this potent vasoconstrictor have been under investigation. The peptide's activities are mediated through specific receptors, which can be classified by their different affinity to ET-1 and ET-3. So far now the DNA sequences of an $\mathrm{ET}_{\mathrm{A}}$ receptor and an $\mathrm{ET}_{\mathrm{B}}$ receptor subtype have been analyzed $[2,3]$. Increasesd ET-1 levels were found in pulmonary diseases such as primary pulmonary hypertension [4], asthma and sepsis [5-7]. The aim of this study was to examine the potential involvement of ET-1 as a mediator of the acute pressure reaction after air embolism. For this purpose, the effects of the $\mathrm{ET}_{\mathrm{A}}$ receptor antagonist LU135252 [8,9] and the $\mathrm{ET}_{\mathrm{B}}$ receptor antagonist $\mathrm{BQ788}[10]$ on vascular resistance after air injection were tested in the isolated, blood perfused rabbit lung. The effects of the simultaneous application of LU135252 and diclofenac were additionally analyzed. There is some evidence that the vascular reactions of ET-1 are in part mediated via the activation of other mediator systems [11, 12]. The activation of the cyclooxygenase pathway, resulting in enhanced thromboxane $\mathrm{A}_{2}\left(\mathrm{TXA}_{2}\right)$, is probably involved in the mediation of ET-1 induced vasoconsriction [13]. To analyze the potential role of $\mathrm{TXA}_{2}$ during the vascular reactions after air injection, the cyclooxygenase inhibitor diclofenac was used in our model.

\section{Materials and methods}

The lung model

Rabbits of either sex weighing $2900 \pm 185 \mathrm{~g}$ (mean \pm SD) were anesthetized with pentobarbital sodium $(60-80 \mathrm{mg} / \mathrm{kg}$ ) and anticoagulated with heparin-sodium (1000 IE/kg body weight). After tracheostomy the animals were mechanically ventilated via a tracheal tube. After a thoracotomy, the pulmonary artery was cannulated and immediately perfused with saline bovine serum albumin (BSA) solution. The lungs were removed from the thorax $[14,15]$ The isolated lungs were suspended from an electronic weight balance (Hottinger. Baldwin Messtechnik Type U1, Darmstadt, Germany) in a temperature-controlled $\left(37^{\circ} \mathrm{C}\right)$ and humidified cham ber. Ventilation of the lungs was performed with $4 \% \mathrm{CO}_{2}$ in air (frequency $25 / \mathrm{min}$. tidal volume $30 \mathrm{ml}$, PEEP $0.5-1.0 \mathrm{~cm} \mathrm{H}_{2} 0$ ). The pulmonary arterial pressure (PAP), airway pressure (AP) and weight of the isolated lungs were recorded continuously by means of pressure and weight transducers. Due to constant perfusion flow, the alterations of perfusion pressure directly reflect alterations of pulmonary vascular resistance. Intermittently, samples of perfusate were taken for calculations of $\mathrm{pO}_{2}, \mathrm{pCO}_{2}$ and $\mathrm{O}_{2}$ saturation (ABL 330, Radiometer Copenhagen) and determinations oncotic pressure (Onkometer BMT 921, Dr. Karl Thomae GmbH, Biberach. GERMANY). Initially the lungs were perfused with saline BSA solution using low flow rates in the opened circulatory system. The perfusion fluid was then exchanged for fresh buffer via two separate perfusion circuits 2 min after the beginning of the extracorporeal circulation and again after $30 \mathrm{~min}$, when the flow was increased up to $200 \mathrm{ml} / \mathrm{min}$. Subsequently,
$20 \mathrm{ml}$ of autologous blood were added to the perfusate within $10 \mathrm{~min}$.

During the whole experiment the flow was maintained at $200 \mathrm{ml} / \mathrm{min}$. The addition of blood to the saline solution did not alter the PAP or the lung weight. During perfusion the integrity of the microcirculation was maintained for more than $5 \mathrm{~h}$ in our model. Homogenous capillary organ perfusion and the absence of structural endothelial damage (e.g., vacuolization, mitochondrial disintegration or the hydropic swelling of endothelial cells) could be verified by light and electronmicroscopic controls. No relevant alterations, in terms of vascular tone $(< \pm 2 \mathrm{mmHg})$, permeability (weight increase $<1.5 \mathrm{~g}$ ) or mediator release, occurred during this observation period. The entry criteria for acceptance in the present study were that the lungs had a homogenous white appearance without signs of hemostasis or edema formation (weight gain $0 \mathrm{~g} / \mathrm{min}$ ), and without changes in pulmonary vascular pressure ( $\leq \pm 1 \mathrm{mmHg}$ ) during the $30 \mathrm{~min}$ equilibration period.

\section{Experimental protocol}

Thirty-six lung preparations were randomly assigned to six groups containing six lungs each. Six lungs without intervention served as a control group. Following a 30 -min equilibration period, lung embolism was induced by an injection of $0.75 \mathrm{ml}$ air into the pulmonary artery (reference, $n=6$ ). In the other experimental groups either LU135252 $\left(10^{-6} \mathrm{M}, n=6\right)$, or BQ788 $\left(10^{-6} \mathrm{M}: n=6\right)$, or diclofenac $(10 \mu \mathrm{g} / \mathrm{ml}, n=6)$ or LU135252 and diclofenac $\left(10^{-6} \mathrm{M}\right.$ and $10 \mu \mathrm{g} / \mathrm{ml}$, respectively, $n=6$ ) were added to the perfusate 10 min prior to air injection. Immediately before and at defined time points $(2.5,5,10,15,30,60 \mathrm{~min})$ after embolism perfusate samples were taken to determine ET-1 and $\mathrm{TXA}_{2}$ concentrations.

\section{Enzyme-linked immunosorbent assay of ET-1}

Endothelin- 1 was assayed from $100 \mu$ of saline solution by enzyme immunoassay. The cross-reactivity of anti-ET-1 antibody was $100 \%$ with ET-1, more than $100 \%$ with ET-2, less than $0.001 \%$ with ET-3, $0.07 \%$ with big ET-1, and less than $0.0006 \%$ with Sarafotoxin $6 \mathrm{~b}$.

\section{Radioimmunoassay of $T X B_{2}$}

Thromboxane $\mathrm{B}_{2}\left(\mathrm{TXB}_{2}\right)$ was assayed serologically from $100 \mu \mathrm{l}$ of recirculating buffer solution as a stable hydrolysis product of thromboxane $\mathrm{A}_{2}$ by radioimmunoassay according to a method described by Peskar [16]. Radioactivity was quantified with a Philips PW 4700 liquid scintillation counter. The results were obtained by standard dose-response curves. The cross-reactivity of $\mathrm{TXB}_{2}$ antiserum with prostaglandin $\mathrm{D}_{2}$ was $2.7 \%$, and $0.05 \%$ with 6 -keto $\mathrm{PGF}_{1} \alpha, \mathrm{PGE}_{2}, \mathrm{PGE}_{1}, \mathrm{PGF}_{1} \alpha, 13,14$-dihydro-15-keto $\mathrm{PGE}_{2}$, and 13,14-dihydro-15-keto $\mathrm{PGE}_{2} \alpha$.

\section{Materials}

This study was approved by the Animal Subject Protection Committee of the University of Giessen. The care and handling of animals conformed to the Guiding Principles in the Care and Use of Animals as approved by the Council of American Physiologic Society.

Saline solution contained $2.4 \mathrm{mmol} / \mathrm{calcium}$ chloride-dihydrate, $1.3 \mathrm{mmol} / \mathrm{l}, 4.3 \mathrm{mmol} / \mathrm{l}$ potassium chloride, $1.1 \mathrm{mmol} / \mathrm{l}$ potas. 
Fig. 1 Changes in pulmonary arterial pressure (PAP) after air injection $(0.75 \mathrm{ml})$ in untreated controls $(n=6)$ and in groups pretreated with the $E T_{A}$ receptor antagonist LU135252

$\left(10^{-6} \mathrm{M} ; n=6\right)$ or with the $\mathrm{ET}_{\mathrm{B}}$ receptor antagonist $\mathrm{BQ788}$ $\left(10^{-6} \mathrm{M} ; n=6\right)$. The PAP increase after air embolism was only significantly reduced by LU135252. Data are presented as mean values \pm standard error of the mean (SEM). ${ }^{* *} p<0.01$; **** $p<0.001$ (ANOVA)

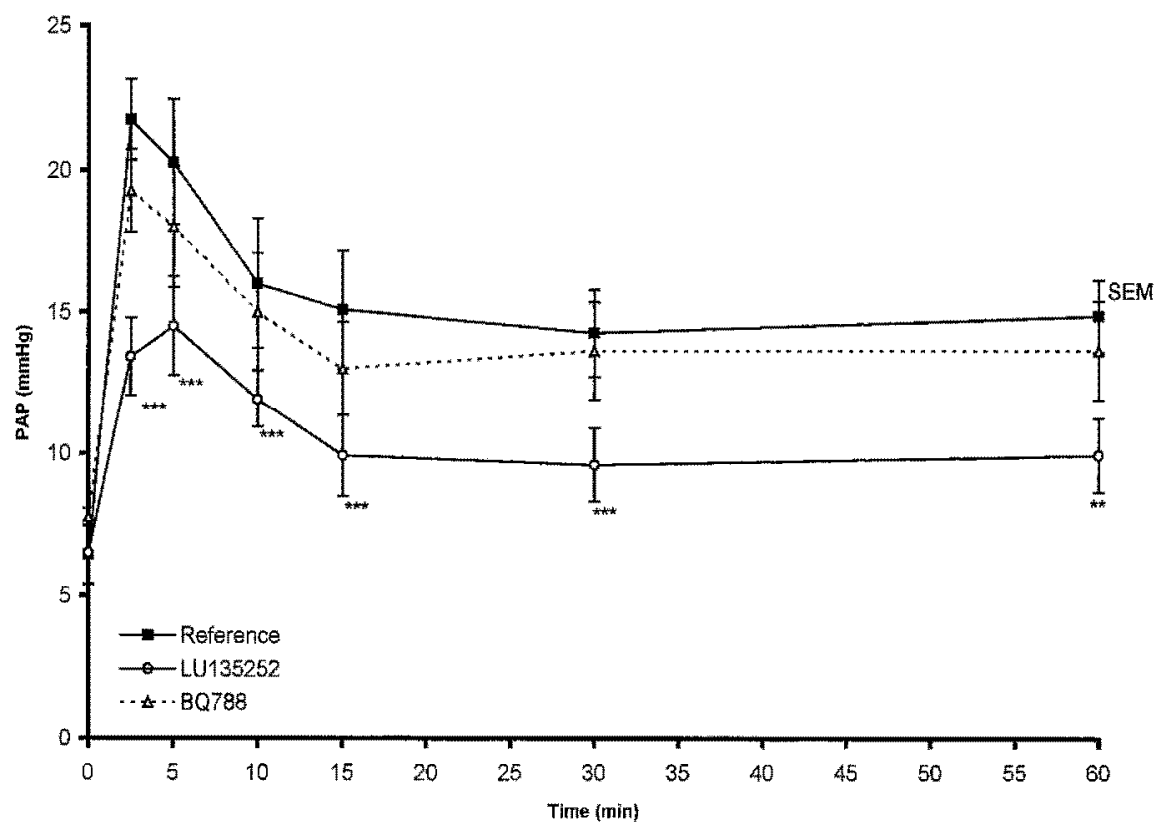

sium hydrogen phosphate, $125 \mathrm{mmol} / 1$ sodiumchloride, $2.5 \mathrm{~g} / \mathrm{lglu}$ cose and $1 \mathrm{mg} / \mathrm{ml}$ BSA (bovine serum albumin, Serva, Heidelberg, GERMANY). To adjust the $\mathrm{pH}$ to $7.4, \mathrm{NaHCO}_{3} 8.4 \%$ was used. Twenty milliliters of autologous blood were acquired after ligation and cannulation of the inferior vena cava. Diclofenac-sodium (Voltaren) was purchased from Ciba-Geigy (Wehr, GERMANY). Based on dose response studies, diclofenac was given in a concentration $(10 \mu \mathrm{g} / \mathrm{ml})$ which has been shown to inhibit the generation of cyclooxygenase products completely. A complete blockade of the cyclooxygenase pathway was achieved when diclofenac was added to the perfusion fluid 3 min prior to direct stimulation of the arachidonic acid metabolism by injection of calcium ionophore or arachidonic acid (unpublished data). The selective $\mathrm{ET}_{\mathrm{A}}$ receptor antagonist LU135252 was a generous gift from Knoll AG (BASF Pharma, Ludwigshafen, GERMANY). LU135252 is a substituted propionic acid derivate with $\mathrm{ET}_{\mathrm{A}}$ receptor affinity in the low nmol/l range $[8,9]$. The dose of LU135252 $\left(10^{-6} \mathrm{M}\right)$ used was based on dose response studies $\left(10^{-6}-10^{-9} \mathrm{M}\right)$ which showed a complete inhibition of vascular reactions after injection of ET-1 in the concentration $\left(10^{-8} \mathrm{M}\right)$ used in our model (unpublished data). BQ788 was obtained from Alexis (Läufelfingen, Switzerland). The dose of BQ788 $\left(10^{-6} \mathrm{M}\right)$ used was based on previous publications [10, 17].

The doses of the antagonists LU135252, BQ788 and diclofenac were tested in pilot studies without any additional intervention. In these experiments they did not alter $\mathrm{PAP}$, thromboxane $\mathrm{A}_{2}$ levels and lung weight during the observation period of $210 \mathrm{~min}$.

Statistical analysis

The data are presented as the mean \pm standard error of the mean (SE). Differences between the groups were tested by one-way analysis of variance (ANOVA) followed by Scheffé's multiple range test (Statgraphics plus for Windows). Statistical significance was accepted at $p$ less than 0.05 .

\section{Results}

Pulmonary vascular reactions after air embolism

In the control group, hing weight was unaltered during the observation period $(\Delta$ weight $= \pm 1.2 \mathrm{~g})$. PAP remained between $7.5 \pm 1.1 \mathrm{mmHg}$ (baseline) and $10.2 \pm$ $1.2 \mathrm{mmHg}$. Air injection $(0.75 \mathrm{ml})$ resulted in an immediate increase in PAP (21.78 $\pm 1.4 \mathrm{mmHg})$ after $2.5 \mathrm{~min}$ ( $p<0.01$ vs control group). Thirty minutes after the induction of embolism, the PAP returned nearly to baseline values (Fig.1). Before, and $60 \mathrm{~min}$ after, air injection there was no significant difference between the control and reference groups. No signs of edema formation occurred during the observation period of $60 \mathrm{~min}$. The PAP increase was parallelled by a generation of $\mathrm{TXA}_{2}$ (from $120 \pm 45 \mathrm{pg} / \mathrm{ml}$ at $0 \mathrm{~min}$ to $980 \pm 150 \mathrm{pg} / \mathrm{ml}$ at $5 \mathrm{~min}, p<0.01$ vs $0 \mathrm{~min}$ ) (Fig. 2). ET-1 was not detectable in the perfusate.

Effects of the endothelin receptor antagonists LU135252 and BQ788 on PAP after air injection

Pretreatment with the $\mathrm{ET}_{\mathrm{A}}$ receptor antagonist LU135252 $\left(10^{-6} \mathrm{M}\right)$ significantly reduced the PAP increase after air embolism $(p<0.001)$. The pressure reached only a value of $13.4 \pm 1.4 \mathrm{mmHg}$ at $2.5 \mathrm{~min}$ $(21.8 \pm 1.4 \mathrm{mmHg}$ in the reference group) and $14.5 \pm 1.8 \mathrm{mmHg}$ at $5 \mathrm{~min}(20.3 \pm 2.2 \mathrm{mmHg}$ in the reference group). The PAP returned to baseline values $15 \mathrm{~min}$ after air injection $(9.9 \pm 1.4 \mathrm{mmHg}$ vs $15.1 \pm 2.1 \mathrm{mmHg}$ in the reference group; $p<0.001$ ) (Fig. 1). No significant difference in PAP occurred be- 




Fig. 2 Thromboxane $\mathrm{A}_{2}\left(\mathrm{TXA}_{2}\right)$ concentrations in the perfusate after air injection $(0.75 \mathrm{ml}$; control; $n=6)$. The generation of $\mathrm{TXA}_{2}$ after air embolism was significantly reduced by the $\mathrm{ET}_{\mathrm{A}}$ receptor antagonist LU135252 $\left(10^{-6} \mathrm{M} ; n=6\right)$ whereas the $\mathrm{ET}_{\mathrm{B}}$ receptor antagonist BQ788 $\left(10^{-6} \mathrm{M} ; n=6\right)$ was without marked effects. Data are presented as mean values \pm standard error of the mean (SEM). $* p<0.05 ; * *^{*} p<0.01$ (ANOVA)

tween the LU135252 and the control groups from $15 \mathrm{~min}$ until the end of the observation period. The generation of $\mathrm{TXA}_{2}$ was also reduced as compared to the reference group $(420 \pm 123 \mathrm{pg} / \mathrm{ml} ; p<0.05)$ (Fig. 2 ).

The administration of the $\mathrm{ET}_{\mathrm{B}}$ receptor antagonist $\mathrm{BQ788}\left(10^{-6} \mathrm{M}\right)$ did not reduce the vascular pressure response after embolism. A PAP maximum of $19.3 \pm$ $1.5 \mathrm{mmHg}$ at $2.5 \mathrm{~min}$ was recorded $(21.8 \pm 1.4 \mathrm{mmHg}$ in the reference group) and at $30 \mathrm{~min}$ the PAP reached $13.6 \pm 1.7 \mathrm{mmHg}(14.3 \pm 1.6 \mathrm{mmHg}$ in the reference group) (Fig. 1). Furthermore, the generation of TXA was not influenced by BQ788 (860 $\pm 147 \mathrm{pg} / \mathrm{ml})$ (Fig. 2).

\section{PAP after pretreatment with diclofenac}

The cyclooxygenase inhibitor diclofenac $(10 \mu \mathrm{g} / \mathrm{ml})$ was used to quantify the potential involvement of $\mathrm{TXA}_{2}$ in the pressure reaction after air injection. Pretreatment with diclofenac did not significantly attenuate the initial pressure response to air embolism $(16.2 \pm 0.7 \mathrm{mmHg}$ at $2.5 \mathrm{~min}$ ) but significantly reduced the PAP in the further observation period from 2.5 min until 60 min after air embolism (11.2 $\pm 0.8 \mathrm{mmHg} ; p<0.001$ vs reference). PAP baseline values were reached at $10 \mathrm{~min}(9.4 \pm$ $1.1 \mathrm{mmHg} ; p<0.001$ vs reference) (Fig. 3).

\section{Effects of the simultaneous administration of LU135252 and diclofenac on PAP after embolism}

The simultaneous administration of LU135252 $\left(10^{-6} \mathrm{M}\right)$ and diclofenac $10 \mu \mathrm{g} / \mathrm{ml}$ significantly reduced the PAP maximum at $2.5 \mathrm{~min}(13.6 \pm 0.6 \mathrm{mmHg} ; p<0.001$ vs reference). At this time point, the PAP was in the same range as had been recorded for the LU135252 group (13.4 $\pm 1.4 \mathrm{mmHg}$ ). Until the end of the observation period PAP remained significanty reduced $(9.0 \pm$ $0.8 \mathrm{mmHg} ; p<0.001)$.
Fig. 3 Changes in pulmonary arterial pressure (PAP) after air injection $(0.75 \mathrm{ml})$ in untreated controls $(n=6)$ and in lungs pretreated with the cyclooxygenase inhibitor diclofenac $(10 \mu \mathrm{g} / \mathrm{ml} ; n=6)$ or a combination of LU135252 $\left(10^{-6} \mathrm{M}\right)$ and diclofenac $(10 \mu \mathrm{g} / \mathrm{ml} ; n=6)$. $2.5 \mathrm{~min}$ after air embolism, the PAP reduction in the LU135252 and diclofenac groups was significant as compared to the controls, whereas the diclofenac group reached significant differences at $5 \mathrm{~min}$. Data are presented as mean values \pm standard error of the mean (SEM). **** $p<0.001$ (ANOVA)






\section{Discussion}

Many clinical practices, such as cardiopulmonary bypass and thoracic surgery, are associated with the risk of air embolism [18, 19]. It is well known that air injection into a central vein is followed by a massive increase in PAP [20-22], as was seen in the present study. The mechanism of PAP increase after air embolism has been described as an interaction of mechanical vascular obstruction by the gas followed by the release of mediators [22]. The aim of our study was to investigate whether or not ET-1 is one of those mediators. Reviewing the data in the literature, it is still unclear whether ET-1 is related to the pressure reaction following air injection. Some data point out the importance of ET- 1 as an mediator of the PAP increase after embolism [23] but reports to the contrary also exist [24]. In the present study, the pulmonary vascular reactions after air embolism were investigated in a rabbit lung model perfused with a saline solution enriched with $10 \%$ of autologous blood.

Air injection into the pulmonary artery was followed by an immediate PAP increase which was parallelled by the generation of $\mathrm{TXA}_{2}$. Pretreatment with the ET $\mathrm{A}_{\mathrm{A}}$ receptor antagonist LU135252 significantly reduced the pressure reaction after air embolism, while the $E T_{B}$ receptor antagonist BQ788 was without any effect. The effect of an $\mathrm{ET}_{\mathrm{A}}$ receptor antagonist on PAP after cmbolism was also supported by pilot experiments using the selective $\mathrm{ET}_{\mathrm{A}}$ receptor antagonist $\mathrm{BQ123}$ (unpublished data). The hypothesis of ET-1 related PAP increase after gas injection into the pulmonary artery has been supported by Wang et al. [23]. They were able to demonstrate increased ET-1 levels after continuous air infusion into the pulmonary artery of isolated rat lungs. In the present study ET-1 was not detectable in the perfusate. Since ET-1 is released in small amounts as a paracrine substance which is diluted in $200 \mathrm{ml}$ of perfusate, it is not surprising that ET-1 was not detectable in our setting. Another fact is the well known clearing capacity of the pulmonary circulation, which is able to clear about $85 \%$ of ET-1 with the first pass [25], especially in the presence of granulocytes with their high potency to degrade ET-1 by proteases [26]. Although investigators believe that cells do not store ET-1 [27], there is some evidence that endothelial cells can release big ET-1, which may be converted to active ET-1 by granulocytes. The postulated cooperative ET-1 synthesis between endothelial cells and granulocytes is supported by investigations in which granulocytes were found to induce endothelin-1 mRNA expression in vascular endothelial cells [28]. The cytosolic fraction of granulocytes is also able to convert big ET-1 to the active ET-1 $[29,30]$ by a cytosolic neutral protease [31].

The ET-1 induced effects seem to be mediated via $E T_{\mathrm{A}}$ receptors since the $E T_{\mathrm{A}}$ receptor antagonist LU135252 was found to reduce the pressure reaction af- ter air injection. $\mathrm{ET}_{\mathrm{A}}$ receptors have been described as the predominant ET receptor subtype in pulmonary circulation $[32,33]$. Since $\mathrm{ET}_{\mathrm{B}}$ receptor related pulmonary vasoconstriction has also been observed $[34,35]$, the effects of the $\mathrm{ET}_{\mathrm{B}}$ receptor antagonist $\mathrm{BQ} 788$ on the PAP increase due to air embolism were investigated. The $\mathrm{ET}_{\mathrm{B}}$ receptor antagonist $\mathrm{BQ788}$ failed to inhibit the pressure reaction after air embolism. From the present data we conclude that ET-1 induced vasoconstriction in pulmonary circulation is mainly mediated via $\mathrm{ET}_{\mathrm{A}}$ receptors. This hypothesis was supported by studies demonstrating no effects of the $\mathrm{ET}_{\mathrm{B}}$ receptor agonist sarafotoxin $\$ 6 \mathrm{c}$ on pulmonary vessels $[36,37]$. On the other hand, the inhibition of ET-1 related PAP increase was achieved using selective $E T_{A}$ receptor antagonists $[38$, 39 ].

In the present study a marked increase in $\mathrm{TXA}_{2}$ concentrations was observed after air embolism. In accordance with previous publications [23], the crucial role of $\mathrm{TXA}_{2}$ as a mediator of the pressure reaction due to air injection was evidenced by increased $\mathrm{TXA}_{2}$ concentrations in the perfusate and the significantly reduced PAP levels after pretreatment with the cyclooxygenase inhibitor diclofenac. The PAP increase was significantly reduced by the $\mathrm{ET}_{\mathrm{A}}$ receptor antagonist LU135252 during the whole experiment. Furthermore, LU135252 markedly reduced the enhanced $\mathrm{TXA}_{2}$ generation after embolism. In contrast to this, diclofenac only attenuated the sustained pressure reaction. From the current data it can be postulated that the release of ET-1 may activate the cyclooxygenase pathway resulting in increased TXA, levels. This hypothesis is supported by the finding that the simultaneous administration of LU135252 and diclofenac significantly reduced the initial pressure increase as observed in the LU135252 group, while PAP levels were similar to those in the diclofenac group during the further observation period. Furthermore, the activation of $\mathrm{TXA}_{2}$ generation by ET-1 has also been previously reported [40].

In summary we conclude that the PAP increase after air embolism in the lung is mainly mediated by ET-1 via $\mathrm{ET}_{\mathrm{A}}$ receptors. The activation, probably $\mathrm{ET}-1$ related, of the cyclooxygenase pathway resulting in a generation of TXA $\mathrm{T}_{2}$ seems to be essentially involved in the pressure reaction due to air injection.

Acknowledgements The authors thank P. Müller for excellent assistance. This study was supported by a grant from the Faculty of Clinical Medicine Mannheim, University of Heidelberg 


\section{References}

1. Yanagisawa $M$, Kurihara $H$, Kimura $S$, Tomobe Y, Kobayashi M, Mitsui Y, Yazaki Y, Katsutoshi G, Masaki T (1988) A novel potent vasoconstrictor peptide produced by vascular endothelial cells. Nature 332: 411-415

2. Arai $\mathrm{H}$, Hori $\mathrm{S}$, Aramori H, Ohkubo $\mathrm{H}$. Nakanishi S (1990) Cloning and expression of a cDNA encoding an endothelin receptor. Nature 348: 730-732

3. Sakurai T, Yanagisawa M. Takuwa Y, Miyazaki $H$, Kimura S, Goto K, Masaki $T$ (1990) Cloning of a cDNA encoding a non-isopeptide-selective subtype of the endothelin receptor. Nature 348: $732-735$

4. Giaid $A$, Yanagisawa $M$, Langleben $D$, Michel RP, Levy R, Shennib H, Kimura $S$. Masaki T, Duguid WP, Path FRC, Stewart DJ (1993) Expression of endothelin-1 in the lungs of patients with pulmonary hypertension. N Engl J Med 328: 1732-1739

5. Chen WY, Yu J, Wang JY (1995) Decreased production of endothelin-1 in asthmatic children after immunotherapy. J Asthma 32: 29-35

6. Vittori E. Marini M, Fasoli A, DeFranchis R. Mattoli S (1992) Increased expression of endothelin in bronchial epithelial cells of asthmatic patients and effects of corticosteroids. Am Rev Respir Dis 146: 1320-1325

7. Mitaka C. Hirata Y, Makita K, Nagura T, Tsunoda Y, Amaha K (1993) Endothelin-1 and atrial natriuretic peptide in septic shock. Am Heart J 126: 466-468

8. Münter $\mathrm{K}$, Hergenröder $\mathrm{S}$, Unger $\mathrm{L}$, Kirchengast M (1996) Oral treatment with an $\mathrm{ET}_{\mathrm{A}}$-receptor antagonist inhibits neointima formation induced by endothelial injury. Pharm Pharmacol Lett 6: $90-92$

9. Riechers H, Albrecht HP, Amberg W, Baumann $\mathrm{E}$, Bernard $\mathrm{H}$, Böhm $\mathrm{HJ}$ Klinge $\mathrm{D}$, Kling $\mathrm{A}$, Müller $\mathrm{S}$, Raschack $M$, Unger $L$, Walker $N$, Wernet $W$ (1996) Discovery and optimization of a novel class of orally active nonpeptidic endothelin-A receptor antagonists. J Med Chem 39: 2123-2128

10. Ishikawa K, Thara M, Noguchi K, Toshikai M, Mino N, Saeki T, Fukuroda T, Fukami T, Ozaki S, Nagase T, Nishikibe M, Yano M (1994) Biochemical and pharmacological profile of a potent and selective endothelin B-receptor antagonist, BO788. Proc Natl Acad Sci USA 91: 4892-4896
11. Thiemermann C, Lidbursy PS, Thomas GR, Vane JR (1989) Endothelin-1 releases prostacyclin and inhibits ex vivo platelet aggregation in the anesthetized rabbit. J Cardiovasc Pharmacol 13 (Suppl 5):S138-S141

12. Macquin-Mavier I, Levame M, Istin N Harf A (1989) Mechanisms of endothelin mediated bronchoconstriction in the guinea pig. J Pharmacol Exp Ther 250: $740-745$

13. Del Basso P, Argiolas L (1995) Cardiopulmonary effects of endothelin-1 in the guinea pig: role of thromboxane A. J Cardiovasc Pharmacol 26 (Suppl 3): $\mathrm{S} 120-\mathrm{S} 122$

14. Koch T, Duncker HP, Rosenkranz $\mathrm{S}$, Van Ackern K, Neuhof H (1992) Alterations of filtration coefficients in pulmonary edema of different pathogenesis. J Appl Physiol 73 (6):2396-2402

15. Seeger $W$, Walmrath $D$, Menger $M$, Neuhof H (1986) Increased lung vascular permeability after arachidonic acid and hydrostatic challenge. J Appl Physiol 61: 1781-1789

16. Peskar BA, Steffens CH, Peskar BM (1979) Radioimmunoassay of 6-ketoprostaglandin F1-alpha in biological material. In: DaPrada M, Peskar BA (eds) Radioimmunoassay of Drugs and Hormones in Cardiovascular Medicine. Elsevier/North-Holland, Amsterdam. p239

17. Fukuroda T, Ozaki S. Ihara M, Ishikawa K, Yano M, Nishikibe M (1994) Synergistic inhibition by $\mathrm{BQ}-123$ and $\mathrm{BO}$ 788 of endothelin-1-induced concentrations of the rabbit pulmonary artery. $\mathrm{Br}$ J Pharmacol 113: 336-338

18. Helmsworth JA, Gall EA, Perrin EV, Braley SA, Flege JB, Kaplan S, Keirle AM (1963) Occurrence of emboli during perfusion with an oxygenator pump. Surgery 53: 177-185

19. Spencer MP (1976) Decompression limits for compressed air determined by ultrasonically detected blood bubbles. I Appl Physiol 40: 229-235

20. Iwao Y, Masuda J, Ochiai R, Higa $S$, Takeda J, Sekiguchi $H$, Nagano $M$ (1995) Does pulmonary air embolism affect the pulsatility of pulmonary capillary blood flow in dogs? (Abstract) Nippon Kyobu Shikkan Gakkai Zasshi 29 (3):338-344

21. Josephson S (1970) Pulmonary hemodynamics during experimental air embolism. Scand J Clin Lab Invest 115 (Suppl) $\$ 9-\$ 30$
22. Perkett EA, Brigham KL, Meyrick B (1988) Continuous air embolization into sheep causes sustained pulmonary hypertension and increased pulmonary vasoreactivity. Am J Pathol 132: 444-454

23. Wang D, Li MH, Hsu K, Shen CY, Chen HI. Lin YC (1992) Air embolism-induced lung injury in isolated rat lungs. J Appl Physiol 72 (4):1235-1242

24. Schmeck J, Koch T, Neuhof H, Van Ackern K (1998) Endothelin-1 is not involved in pulmonary hypertension after lung embolism in isolated perfused rabbit lungs. Appl Cardiopulm Pathophysiol 6:241-246

25. Wagner OF, Vierhapper $H$, Gasic $S$, Nowotny P, Waldhäusl W (1992) Regional effects and clearance of endothelin-1 across pulmonary and splanchnic circulation. Eur J Clin Invest 22: 277-282

26. Patrignani $\mathrm{P}$, Del-Maschio A, Bazzoni G, Daffonchio L, Hernandez A, Modica R. Montesanti L, Volpi D, Patrono C, Dejana E (1991) Inactivation of endothelin by polymorphonuclear leukocyte-derived lytic enzymes. Blood $78(10): 2715-2720$

27. Nakamura S, Naruse $M$, Naruse $K$, Demura H, Uemura H (1990) Immunocytochemical localization of endothelin in cultured bovine endothelial cells. Histochemistry 94: 475-477

28. Marita $T$, Kurihara $H$, Yoshizumi $M$, Maemura K, Sugiyama T, Nagai R, Yazaki $Y$ (1993) Human polymorphonuclear leukocytes have dual effects on endothelin-1: the induction of endothelin-1 mRNA expression in vascular endothelial cells and modification of the endothelin-1 molecule. Heart Vessels $8(1): 1-6$

29. Kaw S, Hecker M, Southan GJ, Warner TD, Vane JR (1992) Characterization of serine protease-derived metabolites of big endothelin in the cytosolic fraction from human polymorphonuclear leukocytes. J Cardiovasc Res 20 (Suppl 12): $\$ 22-\$ 24$

30. Kaw S, Hecker M, Vane JR (1992) The two-step conversion of big endothelin1 to endothelin 1 and degradation of endothelin- 1 by subcellular fractions from human polymorphonuclear leukocytes. Proc Natl Acad Sci USA $89(15): 6886-6890$ 
31. Sessa WC, Kaw S, Zembowicz A, Anggard E, Hecker M, Vane JR (1991) Human polymorphonuclear leukocytes generate and degradate endothelin-1 by two distinct neutral proteases. J Cardiovasc Pharmacol 17(Suppl 7):S34-\$38

32. DiCarlos VS, Chen SJ, Meng OC, Durand $\mathrm{J}$, Yano $\mathrm{M}$, Chen $\mathrm{YF}$, Oparil $\mathrm{S}$ (1995) $\mathrm{ET}_{\mathrm{A}}$-receptor antagonist prevents and reverses chronic bypoxia-induced pulmonary hypertension in rat. Am J Physiol 269:L690-L697

33. Hay DWP. Hubbard WC. Undem BJ (1993) Endothelin receptor subtypes in human and guinea-pig pulmonary tissues. Br J Pharmacol 110: 1175-1183
34. Fukuroda T, Kobayashi M. Ozaki S. Yano M. Miyauchi T, Onizuka M. Sugishita Y, Goto K, Nishikibe M (1994) Endothelin receptor subtypes in human versus rabbit pulmonary arteries. $J$ Appl Physiol 76 (5):1976-1982

35. LaDouceur DM. Flynn MA, Keiser JA, Reynolds $\mathrm{E}$, Haleen $\mathrm{S}$ (1993) $\mathrm{ET}_{\mathrm{A}}$ and $\mathrm{ET}_{\mathrm{B}}$ receptors coexist on rabbit pulmonary artery vascular smooth muscle mediating contraction. Biochem Biophys Res Commun 196: 209-215

36. Buchan KW, Magnusson H. Rabe KF, Sumner MJ, Watts IS (1994) Characterisation of the endothelin receptor mediating contraction of human pulmonary artery using $\mathrm{BQ} 123$ and Ro 46-2005. Eur J Pharmacol 260:221-225

37. Hay DWP, Luttmann MA, Hubbard WC, Undem BJ (1993) Endothelin receptor subtypes in human and guineapig pulmonary tissues. $\mathrm{Br} J$ Pharmacol 110: $1175-1183$
38. Okada M. Yamashita C. Okada M, Okada K (1995) Contribution of endothelin-1 to warm ischemia/reperfusion injury of the rat lung. Am J Respir Crit Care Med 152: 2105-2110

39. Ishizaki T, Shigemori K. Nakai T, Miyabo S, Hayakawa M, Ozawa T, Voelkel NF. Chang SW (1995) Endothelin-1 potentiates leukotoxin-induced edematous lung injury. J Appl Physiol 79 (4):1106-1111

40. Del Basso P, Argiolas L (1995) Cardiopulmonary effects of endothelin-1 in the guinea pig: role of thromboxane A. J Cardiovasc Pharmacol 26 (Suppl 3):S120-\$122 